\title{
Review
}

\section{The politics of unreason: the Frankfurt School and the origins of antisemitism}

\author{
Lars Rensmann \\ SUNY Press, Albany, New York, 2017, xv + 583 pp., \\ ISBN: 9781438465937
}

Contemporary Political Theory (2019) 18, S280-S283. https://doi.org/10.1057/s41296018-0240-5; published online 25 June 2018

Lars Rensmann's book, The Politics of Unreason, which is devoted to explaining and engaging with the Frankfurt School's ideas vis-à-vis antisemitism, is both important and timely. Rensmann first became interested in exploring the actuality of Critical Theory's approach to the study of antisemitism decades ago, and published a groundbreaking work on that subject, Kritische Theorie über den Antisemitismus, at the end of the twentieth century (Rensmann, 1998). The volume under review here, however, is by no means simply a translation or a re-hash of his earlier study. Rensmann has continued to read widely, and think deeply, about relevant matters in the period since he issued his earlier book. His work, moreover, appears at a moment during which the subjects on which Rensmann focuses have once again - become highly pertinent to contemporary political affairs, and to political theory.

Rensmann has chosen to blend the ideas of the first generation of Critical Theorists, and to present these ideas thematically (rather than, for example, in the historical contexts in which these ideas were created). He argues that it is tenable to speak of the Frankfurt School or Critical Theory collectively because they had a shared project...' (p. 430). He does a fine job presenting the psychoanalytically grounded components of the approach taken by Critical Theory, writes very clearly, and devotes several portions of his book to detailed and compelling examinations of key texts, including, most prominently, the well-known chapter on 'Elements of Antisemitism' in Max Horkheimer and Theodor Adorno's Dialectic of Enlightenment, and those parts of The Authoritarian Personality written by Adorno. Those texts, to be sure, have been closely examined by others. One could, perhaps, quibble with the breadth of Rensmann's contention that 'the relevance and indeed ... centrality of the challenge of antisemitism for the evolution of' the Frankfurt School '... has only marginally been the subject of scholarly inquiry' (p. 1). But few - if any - of the earlier authors who have written on relevant themes have matched Rensmann's thoroughness. Moreover Rensmann discusses not only the

(C) 2018 Macmillan Publishers Ltd., part of Springer Nature. 1470-8914 Contemporary Political Theory Vol. 18, S4, S280-S283 www.palgrave.com/journals 
works noted above, but also texts which have received far less attention in the English-speaking world. I was, for example, very taken by his chapter on 'secondary antisemitism,' which is devoted primarily to analysis of the Frankfurt School's post-Holocaust writings on the effects of the Nazi past in Germany. Some of these texts, experts will recall, have been discussed by the editors of the Englishlanguage volume Guilt and Defense (Adorno, 2010) and in other places. However, Rensmann does an excellent job summarizing and explaining the implications of these relatively late writings, which suggest that 'the way society deals with antisemitism after the Shoah and the status of the Jewish minority' are 'crucial indicators for the state of democratization.' (p. 388).

I hasten to add that Rensmann does not merely introduce his readers to the relevant writings of the Frankfurt School. On the contrary: he asserts from the outset that he is determined 'to move beyond mere exegetical interpretation and the history of ideas' (p. 21). He challenges a number of misunderstandings about the Frankfurt School, notably the notion that the School was devoted to 'apolitical social philosophy and theorizing' (p. 9). As Rensmann convincingly demonstrates, Critical Theory has important things to say to contemporary political theorists. In a concluding chapter, entitled 'Why Critical Theory Matters,' Rensmann argues that current work not only on antisemitism but also on racism and authoritarianism would benefit from reconsideration of the Frankfurt School's ideas - a notion with which I enthusiastically concur.

This is not to say that Rensmann defends the Frankfurt School's approach in knee-jerk fashion. On the contrary, he explicitly (and altogether correctly) notes that 'the Frankfurt School's work on antisemitism is riddled with inner tensions, and ... is certainly not short of problems. Some assumptions ... appear outdated from a contemporary perspective' (p. 396). But these caveats notwithstanding, Rensmann argues that it provides important insights not only into political issues of the past, but also into pressing issues in our own day. Ominous, ongoing, political trends in many lands - including not only Poland and Hungary but also the USA in the period since Rensmann's work appeared corroborate his conclusions. One could shed a great deal of light on authoritarian tendencies in the administration of Donald Trump, for example, by the use of texts written by the first generation of Frankfurt School theorists.

I would, however, note that I was not uniformly convinced by Rensmann's desire to present a blended view of Critical Theory. At some points, the author moves back and forth among texts written by Adorno, Leo Lowenthal, Horkheimer, and others without pausing to examine in detail the extent to which these writers had distinctive views. Similarly Rensmann has chosen not to take a strictly chronological approach, and thus uses works from different periods of time when analyzing specific concepts, skipping back and forth among these periods in ways which may blur their differences. Can one really move seamlessly between pieces written in the 1940s and others written in the 1960s?

(C) 2018 Macmillan Publishers Ltd., part of Springer Nature. 1470-8914 Contemporary Political Theory Vol. 18, S4, S280-S283 S28 
Rensmann claims, in his very first footnote, that 'In this book I include first and foremost the so-called inner circle of the Frankfurt School and the Institute for Social Research, namely Theodor W. Adorno, Max Horkheimer, Leo Löwenthal and Herbert Marcuse. They build the primary cast of characters in this study' (p. 421). It is of course true that Marcuse contributed a great deal to the development of the Frankfurt School's ideas on authority and authoritarianism. This is evident in the opening section of the Institute's collective study Studien über Autorität und Familie, which first appeared in 1936 (Horkheimer, Fromm, Marcuse, et al., 1987, pp. 136-228), and of which Rensmann makes good use. Marcuse's contributions to the study of the relationship between family and authority are also apparent in a number of other, later, writings, which are also discussed by Rensmann. But Marcuse actually played a very minor role in the Frankfurt School's studies of antisemitism per se. Moreover, in one relevant instance, Rensmann, whose work, in general, is very dependable, slipped. He reports that, 'Even though antisemitism had been addressed as a problem in some of Horkheimer's early work and in prior essays by Marcuse and Löwenthal written shortly after the Nazis had taken power, much of the early work of the Institute fails to understand antisemitism as an autonomous phenomenon with its own dynamics' (pp. 16-17). In support of this assertion, Rensmann cites an important essay by Martin Jay, 'The Jews and the Frankfurt School.' However, in the place cited by Rensmann, Jay actually makes precisely the opposite point concerning the work by Marcuse and Löwenthal in the 1930s from that made by Rensmann: 'In their collective project ... Studien über Autorität und Familie ... no specific discussion of anti-Semitism was attempted in either the theoretical or empirical sections of the work. Nor were the Jews mentioned in such Institute treatments of Nazi or völkisch ideology as Herbert Marcuse's "Der Kampf gegen den Liberalismus in der totalitären Staatsauffassung" ... of 1934 or Leo Löwenthal's "Knut Hamsun. Zur Vorgeschichte der autoritären Ideologie" ... of 1937' (Jay, 1980, pp. 137-138). Marcuse was, in the 1930s and 1940s, a key member of the Horkheimer Circle. He was not, however, a major contributor to the Frankfurt School's studies of antisemitism as such.

This, however, is not important to the core arguments made by this volume. Rensmann has produced a major book, and a study with substantial implications for subjects of vital import to contemporary political theory. I agree with his most significant conclusions - including both his sense of the ways in which Critical Theory's work on antisemitism may well have continued resonance, and his sense of the limitations of the Frankfurt School's approach - and recommend this study wholeheartedly. 


\section{References}

Adorno, T.W. (2010). Guilt and Defense: On the Legacies of National Socialism in Postwar Germany. Cambridge, MA: Harvard University Press.

Horkheimer, M., Fromm, E., Marcuse, H., et al. (1987). Studien über Autorität und Familie: Forschungsberichte aus dem Institut für Sozialfoschung. Lüneburg: zu Klampen.

Jay, Martin. (1980). The Jews and the Frankfurt School: Critical Theory's Analysis of Anti-Semitism. New German Critique, 19, 137-149.

Rensmann, L. (1998). Kritische Theorie über den Antisemitismus: Studien zu Struktur, Erklärungspotential und Aktualität. Berlin: Argument Verlag.

Jack Jacobs

John Jay College and the Graduate Center, City University of New York, New York, NY 10019, USA jjacobs@gc.cuny.edu 